\title{
Consequences of Team Job Demands: Role Ambiguity Climate, Affective Engagement, and Extra-Role Performance
}

\section{OPEN ACCESS}

Edited by:

Riccardo Sartori,

University of Verona, Italy

Reviewed by:

Arianna Costantini,

University of Verona, Italy Andrea Scalco,

University of Aberdeen, United Kingdom

*Correspondence:

Remedios López-Liria rll040@ual.es

José M. Aguilar-Parra

jmaguilar@ual.es

${ }^{\dagger}$ Present address:

Remedios López-Liria,

Department of Nursing Science,

Physiotherapy and Medicine,

University of Almería, Almería, Spain

Specialty section:

This article was submitted to

Organizational Psychology,

a section of the journal

Frontiers in Psychology

Received: 11 August 2017 Accepted: 18 December 2017

Published: 09 January 2018

Citation:

Mañas MA, Díaz-Fúnez P, Pecino V,

López-Liria $R$, Padilla $D$ and

Aguilar-Parra JM (2018)

Consequences of Team Job

Demands: Role Ambiguity Climate,

Affective Engagement, and Extra-Role

Performance. Front. Psychol. 8:2292.

doi: 10.3389/fpsyg.2017.02292

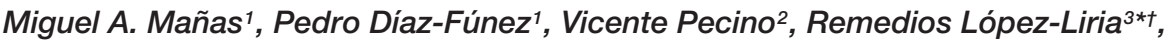
David Padilla ${ }^{4}$ and José M. Aguilar-Parra ${ }^{4 *}$

1 IPTORA Research Team, Department of Psychology, University of Almería, Almería, Spain, ${ }^{2}$ IPTORA Research Team, University of Almería, Almería, Spain, ${ }^{3}$ Hum-498 Research Team, Centre for Neuropsychological Evaluation and Rehabilitation, Department of Nursing Science, Physiotherapy and Medicine, University of Almería, Almería, Spain, ${ }^{4}$ Department of Psychology, University of Almería, Almería, Spain
\end{abstract}

In the absence of clearly established procedures in the workplace, employees will experience a negative affective state. This situation influences their well-being and their intention to behave in ways that benefit the organization beyond their job demands. This impact is more relevant on teamwork where members share the perception of ambiguity through emotional contagion (role ambiguity climate). In the framework of the job demands-resources model, the present study analyzes how high levels of role ambiguity climate can have such an effect to reduce employee affective engagement. Over time it has been associated with negative results for the organization due to a lack of extra-role performance. The sample included 706 employees from a multinational company, who were divided into 11 work teams. In line with the formulated hypotheses, the results confirm the negative influence of the role ambiguity climate on extra-role performance, and the mediated effect of affective engagement in the relationship between the role ambiguity climate and extra-role performance. These findings indicate that the role ambiguity climate is related to the adequate or inadequate functioning of employees within a work context.

Keywords: role ambiguity climate, affective engagement, extra-role performance, job demands-resources model, workplace well-being

\section{INTRODUCTION}

When organizations establish procedures to increase the effectiveness and well-being of employees, the absence of ambiguity in the workplace is a key element in achieving success in such a venture. Among its main benefits is that employees have the capacity to plan, guide, and control the tasks they perform (Bieder and Bourrier, 2013). If in the context of work there are no clearly established procedures, employees must improvise their actions and their behavior will be based on their experience. This leads them to generate latent mistakes or produces direct negative consequences at the organizational level (Ramanujam and Goodman, 2003). If there is clarity in the procedures associated with a role, it increases the degree of accuracy with which the functions associated with that role are developed (Kahn et al., 1964). 
Organizational climate "emerges in organizations through a social information process that concerns the meaning employees attach to the policies, practices, and procedures they experience and the behaviors they observe being rewarded, supported, and expected" (Schneider et al., 2013, p. 381). The clarification of climate as an attribute of the group or organization was an important step for climate research, although some researchers do continue to study climate at the individual level. Work team climate offers an approach to the tangibles on which managers can focus to generate the behaviors they require for effectiveness in the field of organizational studies and encourage a healthy organization (Salanova and Schaufeli, 2009; Schneider et al., 2013).

Role ambiguity is defined as the lack of clarity in understanding the actions to be taken to achieve proposed individual goals (Kahn et al., 1964). The existence of ambiguity with respect to objectives affects employees' understanding of what they are expected to do, generates doubts about how to achieve their own performance objectives, and creates uncertainty as to how their performance will be assessed, and what the consequences will be for completing or failing to complete their objectives (Rogalsky et al., 2016).

The influence of role ambiguity on employees has been described as an affective state, which includes anxiety, depression, lack of self-confidence, or dysfunction in dealing with social situations (Lee and Ashforth, 1996). The consequences of role ambiguity, both at individual and team levels, have been analyzed in a multitude of studies, which underline the reduction of effort (Brown and Peterson, 1993; Tubre and Collins, 2000; Ortqvist and Wincent, 2006; Sakires et al., 2009; Doherty and Hoye, 2011) and decreased satisfaction (Jackson and Schuler, 1985; Thompson et al., 1997; Sakires et al., 2009).

When employees perceive ambiguity, the associated negative emotions will influence other partners due to emotional contagion (Hatfield et al., 1993). The context of the working group becomes the key to understanding how this perception is formed and will affect individuals (Haslam et al., 2003). Only a small number of investigations approach the research of stress from a work team level (Ehrhart, 2004; Peiró, 2008). Therefore, the study of organizational stress climate, including the climate of ambiguity, is currently receiving great interest to advance our understanding of the topic (Länsisalmi et al., 2000; Peiró and González-Romá, 2013).

Extra-role performance has been defined as actions not reflected in job descriptions that have an impact on increased well-being and organizational functioning (Bowling, 2010). In this way, we can differentiate in-role performance, which refers to actions that are "expected, evaluated and rewarded," from extrarole performance, behavior that "arise spontaneously" (Leung, 2007, p. 45). Despite this differentiation, extra-role and in-role performance are strongly associated and extra-role behavior has been the focus of research in recent years (Hoffman et al., 2007; Caillier, 2016). Role ambiguity has shown to play an important role in extra-role performance. From the earliest research on this subject, the results have shown that employees will be more focused on their jobs after their role expectations have been clarified (Kahn et al., 1964). This suggests that when employees are unclear about their expected goals, they will put less effort into their jobs and will perform fewer behaviors that go beyond what is required by their contracts (Caillier, 2016). Chu et al. (2006) provide support for this assertion; they found that role ambiguity was negatively associated with employee willingness to display behavior that contributes to the social and psychological well-being of the organization.

The evaluation of work events as obstacles (i.e., role ambiguity) is related to the reduction of affective engagement, which results in decreased employee well-being (Cavanaugh et al., 2000; Crawford et al., 2010; Schaufeli and Taris, 2014). Kahn (1990, p. 694) introduced the concept of engagement, conceptualizing it as the "harnessing of organization members' selves to their work roles; in engagement, people employ and express themselves physically, cognitively, and emotionally during role performances." Affective engagement, as an indicator of wellbeing, is defined as the experimentation of a state of positive affect related to the work role itself. This process is characterized by an increase in an individual's physical, cognitive, and emotional effort in developing their work (Soane et al., 2012), and has a beneficial effect on thought processes (Fredrickson, 1998) and individual activation (May et al., 2004; Macey and Schneider, 2008).

Several studies have found that the affective bond between the worker and the organization is very sensitive to job demands such as role ambiguity. Jackson and Schuler's (1985) metaanalysis found a significant correlation between role ambiguity and negative affective responses in employees. Recently, research in role ambiguity such as O'driscoll and Beehr (2000), Adae et al. (2008), Brunetto et al. (2011), Caillier (2012), and Chenevert et al. (2013) has determined its significance and negative influence on the affective status of several groups. Recent studies have found that affective engagement also shows a significant mediating effect on organizational outcomes and working environments in their different conceptualizations (Yalabik et al., 2013; Schmitt et al., 2016).

Previously, other authors have sought to understand the behavior of variables in the organizational context by explaining that it is necessary to study complex explanatory models to describe the relationships between these variables (Ehrhart, 2004; Ferris et al., 2009). The job demands-resources (JD-R) model provides a suitable frame of reference for researching the mediating effects in several levels of analysis (Bakker and Demerouti, 2014; Bakker et al., 2014). This assumes that any job has associated factors that influence employee wellbeing through two processes: a health impairment process and a motivational process. In health impairment process, job demands are an important predictor that reduces employee engagement, and over time is associated with negative results for the organization (Bakker et al., 2014). The importance of the JD-R model in the context of employee stress or performance has been supported by studies in different countries and occupational groups (Demerouti et al., 2001; Bakker et al., 2003; Salanova et al., 2005; Ceschi et al., 2017b), and the model has been successfully adapted to multilevel analysis studies (Bakker et al., 2003; Llorens et al., 2006). Recently, authors as Ceschi et al. (2016) have examined the 
role of two personality traits (grit and honesty-humility) in the health impairment process and counterproductive work behavior.

In the framework of the JD-R model, the present study analyzes how the role ambiguity climate is an important predictor for reducing employee affective engagement in terms of job demands, and over time is associated with negative results for the organization due to a lack of extra-role performance.

Thus, we hypothesize that the role ambiguity climate has a negative effect on employee affective engagement and extrarole performance. In addition, affective engagement mediates the relationship between the role ambiguity climate and extra-role performance.

\section{MATERIALS AND METHODS}

\section{Participants}

The final sample of this study comprised 706 employees from a multinational private service sector company based in Spain. The participants' ages were distributed in five intervals (up to 25 years $=22.6 \%, 26-35$ years $=31.2 \%, 36-45$ years $=29.8 \%$, $46-55$ years $=15 \%$, and 56 or more years $=1.4 \%$ ). The sample included $91.2 \%$ males and $8.8 \%$ females. Regarding the contractual relationship, $4.4 \%$ had a temporary part-time contract, $28 \%$ had a full-time temporary contract, $3 \%$ had an indefinite part-time contract, $62.6 \%$ were hired in a full-time indefinite capacity, and $2 \%$ had another type of contract. Most of the sample had higher general secondary education or vocational training (59.4\%), 22.7\% had a bachelor degree, $11 \%$ had a university degree, and others made up the remaining $6.8 \%$. These employees were grouped into 11 work teams (between the administrative office sector, general service assistance, and company support services), with an average team size of 49.2 workers $(S D=21.2)$.

\section{Procedure}

This is a descriptive, cross-sectional study in which data were collected through questionnaires. The Ethical Review Committee at the University of Almería approved the study. The procedure for collecting information began with holding several meetings with those responsible for the company. The questionnaire application was an anonymous form that was completed electronically in the work center, and all workers previously signed an informed consent form. During the application, a member of the research group remained in the room to address any doubts that participants might have about filling the questionnaires. Thus, $100 \%$ of the questionnaires were completed correctly and could be used for further analysis.

\section{Instruments}

This paper adapts the JD-R model to the study of the perception of role ambiguity (as a job demand) analyzed at the level of teamwork, and the mediated effect of the affective engagement between extra-role performance and role ambiguity (Figure 1).

\section{Role Ambiguity}

It has been measured through the questionnaire of Rizzo et al. (1970) adapted by Peiró et al. (1986). The response format is a Likert type of five response alternatives ranging from 1 ("strongly disagree") to 5 ("strongly agree"). It is composed of six items (i.e., "I know clearly what my responsibilities are") and has a Cronbach's alpha coefficient of 0.89 . The corrected item-total correlation ranged from 0.55 to 0.77 . When exceeding the value of 0.40 , it can be concluded that these items are reliable and show their validity (Stewart and Ware, 1992).

\section{Affective Engagement}

It was measured with the Spanish version of the Intellectual, Social, Affective Engagement Scale of Soane et al. (2012) adapted by Mañas et al. (2016). Affective engagement is measured by three items (i.e., "I feel full of energy and strength with my work"). Cronbach's alpha for this scale was 0.94 . A Likert scale with seven categories ranging from 1 ("strongly disagree") to 7 ("strongly agree") was used for their response. The corrected item-total correlation ranged from 0.58 to 0.77 .

\section{Extra-Role Performance}

It was measured using the dimension contextual performance of Job Performance Scale of Goodman and Svyantek (1999). The scale consists of seven items (i.e., "Helps other employees with their work when they have been absent"). The internal consistency of the scale was 0.93. Participants had to answer

Level 2: Work team

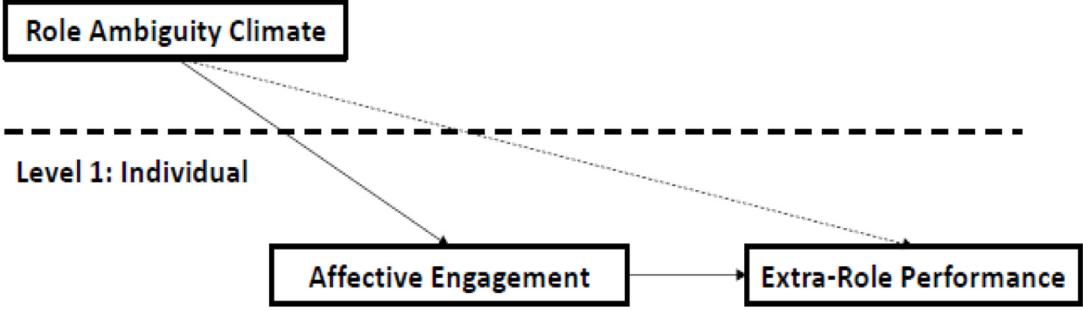

FIGURE 1 | The job demands-resources model applied to the hypothesis model. 
a 7-point scale ranging from 1 ("strongly disagree") to 7 ("strongly agree"). The corrected item-total correlation ranged from 0.65 to 0.71 .

\section{Statistical Analysis}

\section{Aggregation Index}

Role ambiguity has been analyzed as a predictor at the level of the work teams that make up the company. For this, it is necessary to evaluate the degree of agreement in the perceptions of the different members that compose these teams. The ICC1 and ICC2 indices were calculated for this purpose (Bartko, 1976). Although there is no preset fixed cutoff point, for the ICC1 index a value of 0.01 could be considered as a small effect, a value of approximately 0.10 could be considered as an average effect, and values greater than 0.25 could be considered as a large effect (Lebreton and Senter, 2008). For ICC2, values above 0.60 would show support for aggregation. From a consensus-based approach, the Average Deviation Index [ADM $(J)]$ (Burke et al., 1999) and Rwg(J) (James et al., 1993) have been used, and it was concluded that there is a consensus in the unit when the ADM(J) was equal to or less than 1 (Burke et al., 1999). The $\mathrm{Rwg}(J)$ indicates elevated levels of aggregation in the work teams when it shows values greater than 0.70 (Lance et al., 2006). Analysis of variance (ANOVA) has been used in order to determine if there was significant discrimination between the scores displayed by the different groups.

The ICC1 and ICC2 indices obtained for the role ambiguity variable were 0.56 and 0.82 , respectively. The average value of $\operatorname{ADM}(J)$ was 0.89 , while the value of $\operatorname{Rwg}(J)$ was 0.69 . The results of the ANOVA analysis have shown statistically significant differences that support the discrimination between the teams that compose the sample for the analysis of role ambiguity, $F(26,411)=2.60, p<0.001$. These aggregation results indicate the adequacy of the aggregation of the values of the role ambiguity variable between the units that compose the studied sample.

\section{Linear Hierarchical Multilevel Model}

To test the hypotheses, a hierarchical linear model was used (Hofmann et al., 2000), including a mediator variable at the individual level (affective engagement, model 2-1-1). Zhang et al. (2009) argue that, since members of the organization are grouped into work teams, testing the proposed mediation effects by using traditional procedures will result in biased coefficients. Therefore, we followed the procedure recommended by these authors to test the effects of mediation in multilevel contexts.

The effects of mediation can be estimated erroneously when different values are obtained inside and outside the group with respect to magnitude. Therefore, although hierarchical models of mediation can be tested using the traditional Sobel (1982) procedure, more caution is needed. In the present study, we used the analysis of hierarchical models as described in the paper by Zhang et al. (2009). Therefore, the predictor scores have been centered on the mean of the group, and the mean has been included in the level-two interception equation [called CWC (M) or centered within context with the reintroduction of the subtracted means]. This procedure also allows a more accurate test of cross-effects and reduces the problems of estimation at the aggregate level of analysis (Hofmann and Gavin, 1998; Raudenbush and Bryk, 2002). Once we obtained each coefficient of the corrected models, mediation was tested using the Sobel test's step-by-step approach (Baron and Kenny, 1986).

\section{RESULTS}

Mean, standard deviation, internal consistency, and correlations between the variables are shown in Table 1. All correlations were significant and showed the expected pattern of interrelations between the study variables. The role ambiguity climate correlated negatively and significantly with affective engagement $(r=-0.34, p<0.001)$ and with extra-role performance $(r=-0.20, p<0.001)$. On the other side, there was a significant and positive correlation between extra-role performance and affective engagement $(r=0.34, p<0.001)$.

The hierarchical regression model (Table 2) shows the mediating effect of affective engagement on the relationship between the role ambiguity climate and extra-role performance. First, the results in Table 2 show the negative and significant influence of the role ambiguity climate and extra-role performance $(\beta=-0.20, p<0.001)$, and a negative and significant influence of the role ambiguity climate and affective engagement $(\beta=-0.35, p<0.001)$. None of the two outcome variables influence the age variable which was used as a control variable (affective engagement: $\beta=0.04, p$, ns; extra-role performance: $\beta=-0.03, p$, ns). The second step of the regression model includes the mediating effect of affective engagement in the regression equation. The results show that role ambiguity climate and extra-role performance are significantly reduced $(\beta=-0.9, p<0.05)$ in step 1 . The non-significant effects of age are maintained. These results confirm the partial mediation of affective engagement between role ambiguity on teamwork and extra-role performance.

TABLE 1 | Means, standard deviations, internal consistencies, and correlations.

\begin{tabular}{lcccccc}
\hline Variables & $\boldsymbol{M}$ & SD & $\mathbf{1}$ & $\mathbf{2}$ & $\mathbf{3}$ & $\mathbf{4}$ \\
\hline (1) Role ambiguity climate & 1.79 & 0.81 & $(0.89)$ & & & \\
(2) Affective engagement & 5.95 & 1.10 & $-0.39^{* * *}$ & $(0.94)$ & & \\
(3) Extra-role performance & 6.03 & 0.92 & $-0.24^{* * *}$ & $0.34^{* * *}$ & $(0.93)$ & \\
(4) Age & 2.42 & 1.04 & - & - & - & $(-)$
\end{tabular}

Internal consistencies over the main diagonal. ${ }^{*} p<0.05$; $^{* *} p<0.01$; $^{* *} p<0.001$.

TABLE 2 | Results for the hierarchical regression models.

\begin{tabular}{lccccc}
\hline & \multicolumn{2}{c}{ Mediator } & & \multicolumn{2}{c}{ Extra-role performance } \\
\cline { 2 - 3 } \cline { 5 - 6 } Step and variable & $\beta$ & SE & & $\beta$ & SE \\
\hline (1) Age & 0.04 & 0.03 & & -0.03 & 0.03 \\
$\quad$ Role ambiguity climate & $-0.34^{* * *}$ & 0.06 & & $-0.20^{* * *}$ & 0.05 \\
(2) Age & & & & -0.04 & 0.03 \\
Role ambiguity climate & & & & $-0.09^{*}$ & 0.06 \\
Affective engagement $(M)$ & & & & $0.31^{* * *}$ & 0.03 \\
\hline
\end{tabular}

$M$, mediator. ${ }^{*} p<0.05$; $^{* *} p<0.01$; $^{* *} p<0.001$. 


\section{DISCUSSION}

The objective of this study has been to analyze the effects of role ambiguity on work teams, affective engagement, and the extrarole performance of employees, studying if affective engagement mediates the relationship between them. For this purpose, the JD-R model (Bakker and Demerouti, 2014) has been used as a basis for the validation of these hypotheses.

Our first hypotheses argued that role ambiguity would have a significant and negative effect on affective engagement and extra-role performance. The results have confirmed these associations, and suggest that the existence of elevated levels of ambiguity in work teams will reduce affective engagement among employees and extra-role performance behaviors that are carried out in the workplace. Other authors also have found that employees who perceive ambiguity in the definition or execution of their functions experience lower levels of effort (Adae et al., 2008; Moliner et al., 2008; Brunetto et al., 2011; Caillier, 2012). Therefore, the purpose of the clarification of employee roles is the facilitation of the fulfillment of objectives associated with each job, which can have positive effects on the health and well-being of employees (Martínez-Córcoles et al., 2014).

The other hypotheses raised the effect of mediation of affective engagement on the relationship between role ambiguity climate and extra-role performance. Thus, when affective engagement is included in the regression equation, the influence of role ambiguity climate in extra-role performance reduces its influence considerably $(\beta=-0.9, p<0.05)$. This suggests that the existence of a role ambiguity climate in the work teams influences extra-role performance, but mainly through its impact on affective engagement. Previous literature has described role ambiguity's influence on effectiveness, satisfaction with reward for self-effort, and engagement (Ortqvist and Wincent, 2006).

Therefore, extra-role performance is positively influenced by the combination of clear roles in work teams and affective engagement. This is because such employees are able to better manage their existing work resources. In order to achieve their goals, organizations need their employees to personally commit to the achievement of collective goals (Rodríguez-Montalbán et al., 2014). The behavior associated with these collective goals have been denominated in several ways, for example, by extrarole performance (Walumbwa et al., 2010).

This research has considered role ambiguity from a multilevel perspective in line with previous work on stress climates (Ehrhart, 2004; Peiró, 2008; Peiró and González-Romá, 2013; Kozusznik et al., 2015). It proposes the JD-R model as a starting point for the study of the influence of role ambiguity on work teams. This would assist in understanding the variation in worker perceptions and affective engagement perspectives, which would influence effort levels in developing behavior oriented toward extra-role performance. Previous research (Chu et al., 2006; Caillier, 2016) showed, without introducing the affective engagement variable, how role ambiguity affected extra-role performance by analyzing the former from an individual level. In current psychosocial research literature, work team climate is an essential element in the field of organizational studies (Schneider et al., 2013, 2017).

\section{Limitations and Future Research Directions}

The results obtained in this study should be considered under the following limitations. First, the results were obtained from self-reports and could be affected by the variance of the common method; however, the use of intersubjective responses at the team level (aggregate role ambiguity responses) could mitigate this effect. Second, the sample is very specific, and is limited to the collective personnel of a multinational organization located in Spain. Therefore, the generalizability of the results of this study is limited, and they should be considered with this caveat in mind. Despite these limitations, the results are very relevant to further our knowledge of the variables that can help to improve the psychological well-being of employees (in order to obtain inputs for interventions) and to develop healthier organizations. The last limitation is with regard to the cross-sectional study, which does not allow for the observation of causality in the relationships between predictors and outcomes by controlling for stabilities.

Future research should examine the use of other forms of data collection, in addition to self-reported tools (as direct observation or critical incident evaluation interviews). This would provide complementary measures that would corroborate the validity of the data. Second, it is convenient to increase the study sample spectrum in other workplaces, which will allow for a comparison of the results in other work contexts. Of relevance in future research will be the comparison of samples of private and public administrations (Costantini et al., 2017). Third, it is necessary to carry out longitudinal studies that will allow us to analyze the evolution and causal influences, for example, in improving the perception of justice about well-being, group performance, and work-family balance. In addition to the proposed changes based on the limitations of this work, it would also be advisable to deepen the study of the antecedents of the perception of affective commitment in employees. Leadership styles, diverse types of work climates, and other variables can act as filters in obtaining different perceptions of affective commitment in a certain job.

\section{Practical Implications}

The results of the study have important implications for staff management in organizations with shared perceptions of role ambiguity in work teams (as a stress climate). The way in which the perception of role ambiguity is managed is the determinant for achieving employee well-being and engaging all employees, not only those with affective engagement (Soane et al., 2012). The effectiveness of the organization will improve by having employees who are more willing to perform functions beyond those who are described in their job descriptions (extra-role performance). At this point, it is convenient to remember that in situations of high labor demands, it is necessary for employees to commit themselves personally and affectively to the achievement of the proposed collective objectives (Rodríguez-Montalbán et al., 2014). The effectivity of the occurrence of this type of behavior 
has been observed in many studies (MacKenzie et al., 1991; Van Dyne et al., 1995; Vandaele and Gemmel, 2006). These measures will, in turn, promote psychosocial health within organizations and increase employee resilience levels (Meneghel et al., 2016), making public administration a healthy organization (Costantini et al., 2017; Mañas and Alcaraz-Pardo, 2017). In this approach, researchers try to discuss the role of different organizational strategies to preserve an organization's health (Ceschi et al., 2017a).

Finally, the organizations interested in enhancing employee extra-role performance and affective engagement must define their employees' functions or tasks with more comprehensive performance information. This means that employees can proactively use and seek information, initiate a manual structure, and ultimately, when the organization facilitates actions by clarifying, planning operations, communicating changes, and monitoring activities through effective leadership, these activities

\section{REFERENCES}

Adae, H. M., Parboteeah, K. P., and Velinor, N. (2008). Role stressors and organizational commitment: public sector employment in St. Lucia. Int. J. Manpow. 29, 567-582. doi: 10.1108/01437720810904220

Bakker, A. B., and Demerouti, E. (2014). "Job demands-resources theory," in Wellbeing: A Complete Reference Guide, Vol. III, eds P. Y. Chen and C. L. Cooper (Chichester: John Wiley \& Sons), 37-64. doi: 10.1002/9781118539415. wbwell019

Bakker, A. B., Demerouti, E., De Boer, E., and Schaufeli, W. B. (2003). Job demands and job resources as predictors of absence duration and frequency. J. Vocat. Behav. 62, 341-356. doi: 10.1016/S0001-8791(02)00030-1

Bakker, A. B., Demerouti, E., and Sanz-Vergel, A. I. (2014). Burnout and work engagement: the JD-R Approach. Annu. Rev. Organ. Psychol. Organ. Behav. 1, 389-411. doi: 10.1146/annurev-orgpsych-031413-091235

Baron, R. M., and Kenny, D. A. (1986). The moderator-mediator variable distinction in social psychological research: conceptual, strategic, and statistical considerations. J. Pers. Soc. Psychol. 51, 1173-1182. doi: 10.1037/0022-3514.51. 6.1173

Bartko, J. J. (1976). On various intraclass correlation reliability coefficients. Psychol. Bull. 83, 762-765. doi: 10.1037/0033-2909.83.5.762

Bieder, C., and Bourrier, M. (2013). Trapping Safety into Rules: How Desirable or Avoidable Are Procedures? Farnham: Ashgate. doi: 10.1080/00140139.2013. 819675

Bowling, N. (2010). Effects of job satisfaction and conscientiousness on extra-role behaviors. J. Bus. Psychol. 25, 119-130. doi: 10.1007/s10869-009-9134-0

Brown, S. P., Ganesan, S., and Challagalla, G. (2001). Self-efficacy as a moderator of information-seeking effectiveness. J. Appl. Psychol. 86, 1043-1051. doi: 10.1037/ 0021-9010.86.5.1043

Brown, S. P., and Peterson, R. A. (1993). Antecedents and consequences of salesperson job satisfaction: meta-analysis and assessment of causal effects. J. Mark. Res. 30, 63-77. doi: 10.2307/3172514

Brunetto, Y., Farr-Wharton, R., and Shacklock, K. (2011). Supervisorsubordinate communication relationships, role ambiguity, autonomy and affective commitment for nurses. Contemp. Nurse 39, 227-239. doi: $10.5172 /$ conu.2011.39.2.227

Burke, N. J., Finkelstein, L. M., and Dusig, M. S. (1999). On average deviation indices for estimating interrater agreement. Organ. Res. Methods 2, 49-68. doi: $10.1177 / 109442819921004$

Caillier, J. G. (2012). The impact of teleworking on work motivation in a U.S. Federal Government Agency. Am. Rev. Public Adm. 42, 461-480. doi: 10.1177/ 0275074011409394

Caillier, J. G. (2016). Does public service motivation mediate the relationship between goal clarity and both organizational commitment and extra-role behaviours? Public Manag. Rev. 18, 300-318. doi: 10.1080/14719037.2014. 984625 can help to improve role clarity (Kohli, 1989; Brown et al., 2001; Hall, 2008; Yukl et al., 2009).

\section{AUTHOR CONTRIBUTIONS}

MM, PD-F, and VP: contribution to the conception and design of the work; the acquisition and interpretation of data for the work, revising it critically for important intellectual content and final approval of the version to be published. RL-L, DP, and JA-P: contribution to the conception and design of the work; the interpretation of data for the work, revising it critically for important intellectual content and final approval of the version to be published. All authors are accepting and agreeing that the work is original; any methods and data presented are described accurately and honestly; any relevant interests have been disclosed.

Cavanaugh, M. A., Boswell, W. R., Roehling, M. V., and Boudreau, J. W. (2000). An empirical examination of self-reported stress among managers. J. Appl. Psychol. 85, 65-74. doi: 10.1037/0021-9010.85.1.65

Ceschi, A., Costantini, A., Dickert, S., and Sartori, R. (2017a). The impact of occupational rewards on risk taking among managers. J. Pers. Psychol. 16, 104-111. doi: 10.1027/1866-5888/a000184

Ceschi, A., Demerouti, E., Sartori, R., and Weller, J. (2017b). Decision-making processes in the workplace: how exhaustion, lack of resources and job demands impair them and affect performance. Front. Psychol. 8:313. doi: 10.3389/fpsyg. 2017.00313

Ceschi, A., Sartori, R., Dickert, S., and Costantini, A. (2016). Grit or honestyhumility? New insights into the moderating role of personality between the health impairment process and counterproductive work behavior. Front. Psychol. 7:1799. doi: 10.3389/fpsyg.2016.01799

Chenevert, D. V., Doucet, C., Ayed, B. A., and Khalil, A. (2013). Passive leadership, role stressors, and affective organizational commitment: a timelagged study among health care employees. Eur. Rev. Appl. Psychol. 63, 277-286. doi: 10.1016/j.erap.2013.07.002

Chu, C., Lee, M., and Hsu, H. (2006). The impact of social support and job stress on public health nurses' organizational citizenship behaviors in rural Taiwan. Public Health Nurs. 23, 496-505. doi: 10.1111/j.1525-1446.2006. 00599.x

Costantini, A., De Paola, F., Ceschi, A., Sartori, R., Meneghini, A. M., and Di Fabio, A. (2017). Work engagement and psychological capital in the Italian public administration: a new resource-based intervention programme. SA J. Ind. Psychol. 43, 1-11. doi: 10.4102/sajip.v43i0.1413

Crawford, E. R., LePine, J. A., and Rich, B. L. (2010). Linking job demands and resources to employee engagement and burnout: a theoretical extension and meta-analytic test. J. Appl. Psychol. 95, 834-848. doi: 10.1037/a0019364

Demerouti, E., Bakker, A. B., Nachreiner, F., and Schaufeli, W. B. (2001). The job demands-resources model of burnout. J. Appl. Psychol. 86, 499-512. doi: 10.1037/0021-9010.86.3.499

Doherty, A., and Hoye, R. (2011). Board member performance in nonprofit sport organizations. Nonprofit Manag. Leadersh. 22, 108-128. doi: 10.1002/nml.20043

Ehrhart, M. G. (2004). Leadership and procedural justice climate as antecedents of unit-level organizational citizenship behavior. Pers. Psychol. 57, 61-94. doi: 10.1111/j.1744-6570.2004.tb02484.x

Ferris, G. R., Liden, R. C., Munyon, T. P., Summers, J. K., Basik, K. J., and Buckley, M. R. (2009). Relationships at work: toward a multidimensional conceptualization of dyadic work relationships. J. Manag. 35, 1379-1403. doi: $10.1177 / 0149206309344741$

Fredrickson, B. L. (1998). What good are positive emotions? Rev. Gen. Psychol. 2, 300-319. doi: 10.1037/10892680.2.3.300

Goodman, S. A., and Svyantek, D. J. (1999). Person-organization fit and contextual performance: do shared values matter. J. Vocat. Behav. 55, 254-275. doi: $10.1006 /$ jvbe.1998.1682 
Hall, M. (2008). The effect of comprehensive performance measurement systems on role clarity, psychological empowerment and managerial performance. Account. Organ. Soc. 33, 141-163. doi: 10.1016/j.aos.2007.02.004

Haslam, S. A., Postmes, T., and Ellemers, N. (2003). More than a metaphor: organizational identity makes organizational life posible. Br. J. Manag. 14, 357-369. doi: 10.1111/j.1467-8551.2003.00384.x

Hatfield, E., Cacioppo, J. T., and Rapson, R. L. (1993). Emotional contagion. Curr. Dir. Psychol. Sci. 2, 96-100. doi: 10.1111/1467-8721.ep10770953

Hoffman, B. J., Blair, C. A., Meriac, J. P., and Woehr, D. J. (2007). Expanding the criterion domain? A quantitative review of the OCB literature. J. Appl. Psychol. 92, 555-566. doi: 10.1037/0021-9010.92.2.555

Hofmann, D. A., and Gavin, M. B. (1998). Centering decisions in hierarchical linear models: implications for research in organizations. J. Manag. 24, 623-641. doi: 10.1177/014920639802400504

Hofmann, D. A., Griffin, M. A., and Gavin, M. B. (2000). “The application of hierarchical linear modeling to organizational research," in Multilevel Theory, Research, and Methods in Organizations: Foundations, Extensions, and New Directions, eds K. J. Klein and S. W. J. Kozlowski (San Francisco, CA: Jossey-Bass), 467-511.

Jackson, S., and Schuler, R. (1985). A meta-analysis and conceptual critique of research on role ambiguity and role conflict in work settings. Organ. Behav. Hum. Decis. Process. 36, 16-78. doi: 10.1016/0749-5978(85)90020-2

James, R. L., Demaree, R. G., and Wolf, G. (1993). RWG: an assessment of withingroup interrater agreement. J. Appl. Psychol. 78, 306-309. doi: 10.1037/00219010.78.2.306

Kahn, R., Wolfe, D., Quinn, R., Snoek, J., and Rosenthal, R. (1964). Organizational Stress: Studies in Role Conflict and Ambiguity. New York, NY: Wiley.

Kahn, W. A. (1990). Psychological conditions of personal engagement and disengagement at work. Acad. Manag. J. 33, 692-724. doi: 10.2307/256287

Kohli, A. K. (1989). Effects of supervisory behavior: the role of individual differences among salespeople. J. Mark. 53, 40-50. doi: 10.2307/1251378

Kozusznik, M., Rodríguez, I., and Peiró, J. M. (2015). Eustress and distress climates in teams: patterns and outcomes. Int. J. Stress Manag. 22, 1-23. doi: 10.1037/ a 0038581

Lance, C. E., Butts, M. M., and Michels, L. C. (2006). The sources of four commonly reported cutoff criteria what did they really say? Organ. Res. Methods 9, 202-220. doi: 10.1177/1094428105284919

Länsisalmi, H., Peiró, J. M., and Kivimaki, M. I. V. (2000). Collective stress and coping in the context of organizational culture. Eur. J. Work Organ. Psychol. 9, 527-559. doi: 10.1080/13594320050203120

Lebreton, J. M., and Senter, J. L. (2008). Answers to twenty questions about interrater reliability and interrater agreement. Organ. Res. Methods 11, 815-852. doi: $10.1177 / 1094428106296642$

Lee, R. T., and Ashforth, B. E. (1996). A meta-analytic examination of the correlates of the three dimensions of job burnout. J. Appl. Psychol. 81, 123-133. doi: 10.1037/0021-9010.81.2.123

Leung, A. (2007). Matching ethical work climate to in-role and extra-role behaviors in a collectivist work setting. J. Bus. Ethics 79, 43-55. doi: 10.1007/s10551-0079392-6

Llorens, S., Bakker, A. B., Schaufeli, W. B., and Salanova, M. (2006). Testing the robustness of the job demands-resources model. Int. J. Stress Manag. 13, 378-391. doi: 10.1037/1072-5245.13.3.378

Macey, W. H., and Schneider, B. (2008). The meaning of employee engagement. Ind. Organ. Psychol. 1, 3-30. doi: 10.1111/j.1754-9434.2007.0002.x

MacKenzie, S. B., Podsakoff, P. M., and Fetter, R. (1991). Organizational citizenship behavior and objective productivity as determinants of managerial evaluations of salespersons' performance. Organ. Behav. Hum. Decis. Process. 50, 123-150. doi: 10.1016/0749-5978(91)90037-T

Mañas, M. A., and Alcaraz-Pardo, L. (2017). A healthy public administration through healthy organizational practices. Anal. Psicol. 33, 160-167. doi: 10.6018/analesps.33.1.232251

Mañas, M. A., Alcaraz-Pardo, L., Pecino-Medina, V., and Limbert, C. (2016). Validation of the Spanish version of Soane's ISA engagement scale. Rev. Psicol. Trabajo Organ. 32, 87-93. doi: 10.1016/j.rpto.2016.04.002

Martínez-Córcoles, M., Gracia, F. J., Tomás, I., and Peiró, J. M. (2014). Strengthening safety compliance in nuclear power operations: a role-based approach. Risk Anal. 34, 1257-1269. doi: 10.1111/risa.12173
May, D. R., Gilson, R. L., and Harter, L. M. (2004). The psychological conditions of meaningfulness, safety and availability and the engagement of the human spirit at work. J. Occupat. Organ. Psychol. 77, 11-37. doi: 10.1348/ 096317904322915892

Meneghel, I., Martínez, I. M., and Salanova, M. (2016). Job-related antecedents of team resilience and improved team performance. Pers. Rev. 45, 505-522. doi: 10.1108/PR-04-2014-0094

Moliner, C., Martínez-Tur, V., Ramos, J., Peiró, J. M., and Cropanzano, R. (2008). Organizational justice and extra-role customer service: the mediating role of well-being at work. Eur. J. Work Organ. Psychol. 17, 327-348. doi: 10.1080/ 13594320701743616

O'driscoll, M. P., and Beehr, T. A. (2000). Moderating effects of perceived control and need for clarity on the relationship between role stressors and employee affective reactions. J. Soc. Psychol. 140, 151-159. doi: 10.1080/ 00224540009600454

Ortqvist, D., and Wincent, J. (2006). Prominent consequences of role stress: a meta-analytic review. Int. J. Stress Manag. 13, 399-422. doi: 10.1037/10725245.13.4.399

Peiró, J. M. (2008). "Stress and coping at work. New research trends and their implications for practice," in The Individual in the Changing Working Life, eds K. Näswall, J. Hellgren, and M. Sverke (Cambridge: Cambridge University Press).

Peiró, J. M., and González-Romá, V. (2013). "El clima organizacional de estrés: componentes, procesos de aparición, fuerza y efectos," in Proceedings of the Conferencias del XXXIV Congreso Interamericano de Psicología, eds C. Alchieri and J. Barreiros, Brasilia, 131-150.

Peiró, J. M., Meliá, J. L., Torres, M. A., and Zurriaga, R. (1986). La medida de la experiencia de la ambigüedad en el desempeño de roles: El cuestionario general de ambigüedad de rol en ambientes organizacionales. Eval. Psicol. 3, 27-53. doi: 10.1016/j.rpto.2015.04.001

Ramanujam, R., and Goodman, P. S. (2003). Latent errors and adverse organizational consequences: a conceptualization. J. Organ. Behav. 24, 815-836. doi: $10.1002 /$ job.218

Raudenbush, S. W., and Bryk, A. S. (2002). Hierarchical Linear Models: Applications and Data Analysis Methods, Vol. 2. Los Angeles, CA: Sage.

Rizzo, J., House, R., and Lirtzman, S. (1970). Role conflict and ambiguity in complex organizations. Adm. Sci. Q. 15, 150-163. doi: 10.2307/2391486

Rodríguez-Montalbán, R. L., Martínez-Lugo, M., and Salanova, M. (2014). Justicia organizacional, engagement en el trabajo y comportamientos de ciudadanía organizacional: una combinación ganadora. Univ. Psychol. 13, 961-974. doi: 10.11144/Javeriana.UPSY13-3.joet

Rogalsky, K., Doherty, A., and Paradis, K. F. (2016). Understanding the sport event volunteer experience: an investigation of role ambiguity and its correlates. J. Sport Manag. 30, 453-469. doi: 10.1123/jsm.2015-0214

Sakires, J., Doherty, A., and Misener, K. (2009). Role ambiguity in voluntary sport organizations. J. Sport Manag. 23, 615-643. doi: 10.1123/jsm.23.5.615

Salanova, M., Cifre, E., Grau, R., Llorens, S., and Martínez, I. (2005). Antecedentes afectivos de la autoeficacia en profesores y estudiantes universitarios: un modelo causal [Affective antecedents of self-efficacy in university teachers and students: a causal model]. Rev. Psicol. Trab. Organ. 21, 159-176.

Salanova, M., and Schaufeli, W. B. (2009). El Engagement en el Trabajo. Cuando el Trabajo se Convierte en Pasión. Madrid: Alianza.

Schaufeli, W. B., and Taris, T. W. (2014). "A critical review of the job demands-resources model: implications for improving work and health," in Bridging Occupational, Organizational and Public Health, eds G. F. Bauer and O. Hämmig (Amsterdam: Springer), 43-68.

Schmitt, A., Den Hartog, D. N., and Belschak, F. D. (2016). Transformational leadership and proactive work behaviour: a moderated mediation model including work engagement and job strain. J. Occupat. Organ. Psychol. 89, 588-610. doi: 10.1111/joop.12143

Schneider, B., Ehrhart, M. G., and Macey, W. H. (2013). Organizational climate and culture. Annu. Rev. Psychol. 64, 361-388. doi: 10.1146/annurev-psych-113011143809

Schneider, B., González-Romá, V., Ostroff, C., and West, M. A. (2017). Organizational climate and culture: reflections on the history of the constructs in journal of applied psychology. J. Appl. Psychol. 102, 468-482. doi: 10.1037/ apl0000090 
Soane, E., Truss, C., Alfes, K., Shantz, A., Rees, C., and Gatenby, M. (2012). Development and application of a new measure of employee engagement: the ISA Engagement Scale. Hum. Resour. Dev. Int. 15, 529-547. doi: 10.1080/ 13678868.2012.726542

Sobel, M. E. (1982). Asymptotic confidence intervals for indirect effects in structural equation models. Sociol. Methodol. 13, 290-312. doi: 10.2307/270723

Stewart, A. I., and Ware, J. E. (1992). Measuring Functioning and Web-Being: the Medical Outcomes Study Approach. Durham, NC: Duke University Press.

Thompson, D. P., McNamara, J. F., and Hoyle, J. R. (1997). Job satisfaction in educational organizations: a synthesis of research findings. Educ. Adm. Q. 33, 7-37. doi: 10.1177/0013161X97033001002

Tubre, T., and Collins, J. (2000). Jackson and Schuler (1985) revisited: a meta-analysis of the relationship between role ambiguity, role conflict, and job performance. J. Manag. 26, 155-169. doi: 10.1177/0149206300026 00104

Van Dyne, L., Cummings, L. L., and Parks, J. M. (1995). "Extra-role behaviors: in pursuit of construct and definitional clarity (A bridge over muddied waters)," in Research in Organizational Behavior, Vol. 17, eds L. L. Cummings and B. M. Staw (Greenwich, CT: JAI Press), 215-285.

Vandaele, D., and Gemmel, P. (2006). Performance implications of in-role and extra-role behavior of frontline service employees. Paper Presented at the Working Paper of Faculty of Economics and Business Administration (Belgium: Ghent University).

Walumbwa, F. O., Hartnell, C. A., and Oke, A. (2010). Servant leadership, procedural justice climate, service climate, employee attitudes, and organizational citizenship behavior: a cross-level investigation. J. Appl. Psychol. 95, 517-529. doi: 10.1037/a0018867

Yalabik, Z. Y., Popaitoon, P., Chowne, J. A., and Rayton, B. A. (2013). Work engagement as a mediator between employee attitudes and outcomes. Int. J. Hum. Resour. Manag. 24, 2799-2823. doi: 10.1080/09585192.2013.763844

Yukl, G., O’Donnell, M., and Taber, T. (2009). Influence of leader behaviors on the leader-member exchange relationship. J. Manag. Psychol. 24, 289-299. doi: 10.1108/02683940910952697

Zhang, Z., Zyphur, M. J., and Preacher, K. J. (2009). Testing multilevel mediation using hierarchical linear models problems and solutions. Organ. Res. Methods 12, 695-719. doi: 10.1177/1094428108327450

Conflict of Interest Statement: The authors declare that the research was conducted in the absence of any commercial or financial relationships that could be construed as a potential conflict of interest.

The reviewer AC and handling editor declared their shared affiliation.

Copyright (C) 2018 Mañas, Díaz-Fúnez, Pecino, López-Liria, Padilla and Aguilar-Parra. This is an open-access article distributed under the terms of the Creative Commons Attribution License (CC BY). The use, distribution or reproduction in other forums is permitted, provided the original author(s) or licensor are credited and that the original publication in this journal is cited, in accordance with accepted academic practice. No use, distribution or reproduction is permitted which does not comply with these terms. 